Miroslav Bjegović ${ }^{1}$
Mirjana Radovanović $^{2}$
Goran Župac $^{3}$
JEL: Q4,P48

DOI: $10.5937 /$ industrija46-19215

UDC: $351: 620.92$

005.35:620.92

Original Scientific Paper

\title{
National and Energy Security in Terms of Human Development
}

\author{
Article history: \\ Received: 18 October 2018 \\ Sent for revision: 20 October 2018 \\ Received in revised form: 24 November 2018 \\ Accepted: 24 November 2018 \\ Available online: 28 December 2018
}

\begin{abstract}
Governing energy is one of the main challenges for the secure global future. Energy security is integral part of national security system, characterized by strong causal relationship with economic, social and geopolitical movements as a whole. Regardless of the high significance, there are major challenges in defining methodologies for control of the governance in this area. In addition, results of control measurements could be (miss)interpreted and/or intentionally created for certain geopolitical purposes. Methodology analysis, which will be presented in this paper, is Energy Trilemma Index, developed by distinguished World Energy Council. Main objective of this paper is assessment of reliability of this Index, which is done by testing of its methodological concept itself on the sample of 33 countries. Analysis is conducted by review of available reports, general descriptive statistics and data processing. Spearman's rank-order correlation test has been applied to four main variables: three variables - constituents of Energy Trilemma Index and Human Development Index as control variable. Results of this research point to the significant shortcomings of Index itself, because of which it is recommended for all the regulation, strategies and assessments done and/or supported by use of Energy Trilemma Index to be taken with certain level of caution.
\end{abstract}

Keywords: Energy security; National security; Human Development Index

\footnotetext{
${ }^{1}$ Educons University, Faculty of Security Studies, Serbia

2 Educons University, Faculty of Security Studies, Serbia

${ }^{3}$ University of Defence in Belgrade, Serbia
} 
Bjegović M., et al: National and Energy Security in Terms of Human Development

\title{
Nacionalna i energetska bezbednost u funkciji humanog razvoja
}

\begin{abstract}
Apstrakt: Upravljanje energijom je jedan od najvećih izazova globalne bezbednosti u celini. Energetska bezbednost je integralni deo sistema nacionalne bezbednosti, a karatkteriše je jaka međusobna povezanost sa ekonomskim, socijalnim i geopolitičkim promenama u celini. Uprskos velikoj važnosti, evidentni su značajni izazovi u definisanju metodologija za kontrolu upravljanja u ovoj oblasti. Osim toga, rezultati kontrolnih merenja mogu biti pogrešno interpretirani $i$ / ili kreirani upravo sa ciljem dostizanja određenih geopolitičkih ciljeva. Analiza metodologije koja će biti prezentovana u ovom radu se odnosi na Energy Trilemma Index, koji je razvio Svetski energetski savet. Osnovni cilj ovog rada je procena pouzdanosti ovog Indeksa, koja je obavljena putem testiranja samog metodološkog koncepta na uzorku od 33 zemlje. Analiza je obavljena pregledom dostupnih izveštaja, primenom opšte deskriptivne statistike i obradom podataka. Spearman's rank-order correlation test je primenjen na četiri osnovne varijable: tri varijable koje su sastavni elementi Energy Trilemma Indeksa i Indeks Humanog Razvoja kao kontrolna varijabla. Rezultati istraživanja pokazuju da postoje značajna metodološka ograničenja samog Indeksa, zbog čega se preporučuje da se regulative, strategije i procene koje se obavljaju i / ili su podržane primenom ovog Indeksa moraju uzeti sa određenom dozom opreza.
\end{abstract}

Ključne reči: Energetska bezbednost; Nacionalna bezbednost; Human Development Index

\section{Introduction}

Global objective of sustainable energy management is ability to provide a secure, affordable and environmentally sustainable energy system (Al-mulali and Bitni Che Sab, 2018; Zong, Cao and Liu, 2018), including development of conservation policies for the future (Bilgen and Sirikaya, 2018). Energy is essential for the functioning of all economic activities and for the life of citizens. Access to energy and its efficient use greatly contribute to the economic development and social well-being (Cãtãlin, 2016; Rakić, Stanojević and Radjenović, 2015).

Proper energy policy is one of the basic preconditions for the development of each national economy, and can only be achieved by the development and application of an adequate energy strategy. However, energy policy of majority of countries must come out of national frameworks and decision makers should monitor changes that take place on the world's geopolitical scene, adapt to them and anticipate them. Most countries depend on the 
import of energy resources that are concentrated in only a dozen countries of the world. In addition, estimates indicate that the reserves of energy resources are in the same countries, so there is no possibility that resources may be procured from other countries. Therefore, it is necessary to monitor the overall energy and foreign policy of the resource rich countries, as well as the legal documents that are being prepared or in force (Ristić, Mirković Isaeva and Vasić 2018).

In the case of energy policy, decision-making is very complex, because it includes many variables, many of them intangible (Xue and Sun, 2018). In the same time, phenomenon of resources course exists, with evidence that resource dependence negatively affects growth remains convincing (Badeeb, Lean and Clark, 2017). Numerous policies in this field are developed so far, but despite the explicit claims made by legislators, the regulatory gift has the potential to significantly undermine the public interest (Browne, 2018). It is also important to underline power of national governments in regulating this area, because market actors usually have no significant impact on decisionmaking process (Lederer, 2012). Problems in transition towards sustainable governance are especially significant in developing countries. Namely, "while this transition has occurred relatively smoothly in developed country contexts, in developing countries the diffusion of the regulatory state has produced manifestly different forms of governance, stressing the regulatory capacity of existing and newly formed regulatory bodies" (Jarvis, 2010).

Governing is complex process, which, among other, requires proper techniques and tools for measurement of its implementation effectiveness. It is even more important when it comes to security and geopolitics, which is strongly associated with energy (and resources) in general. Measurement of achieved level serves as a basic point for planning the future, or, in case of poor performance, gives the directions for corrections. In case of energy and environment, proper control of governance is even more important, because energy and environment strategies are created to last for more years, even decades. Any mistake (or overlooked problem) can cause problems on long run (Radovanović, Filipović and Golušin, 2018).

There are numerous specificities which have impact on energy security, but it goes beyond traditional understanding of energy security as simple security of supply. Significant improvements have been made, while new methodologies are taking into account new variables, data processing and interpretation of the results. Environmental issues have been recognized, harmful effect of fossil fuels use is well known, volatility differences among oil, gas and coal make the planning and implementation of sustainable energy strategies more difficult (Bildirici and Bakirtas, 2018; Gent \& Tomei, 2017).

There is certain number of methodologies developed (by institutions and individuals) with the aim to measure specificities of energy / environment 
nexus, and all of them have advantages and shortcomings. International Energy Agency, OECD, US Chamber of commerce, EU Joint Research Centre, World Energy Council (to mention only most influential ones) developed certain methodologies, which serve as a base for decision making in area of energy security and environmental sustainability planning. Approaches to the issue, suggested by these institutions, are different and they are subject of scientific analysis independence, which can be questioned. Therefore, (what makes control even more challenging) there is no universally accepted methodology for measurement in this area so far - which opens door for speculations and intentional or unintentional presentation of the results. It must be accepted (as an axiom) that it is not possible to develop perfect methodology, but appearance and use of methodologies, which are wrongly conceptualized, must be detected and policy makers should be warned. That is the only way in which planning can be more effective and enable optimal use of all the necessary resources (Lior, Radovanović and Filipović, 2018).

\section{Literature review}

Various approaches to measuring of the energy security have been developed so far and there are ten most often used methodologies (MuñozDelgado, 2011): Shannon-Wiener index, Energy Security Indexes, Supply/Demand Index for long term security of supply, Oil Vulnerability Index, Vulnerability index, Risky External Energy Supply, Socio-economic Energy Risk, The US Energy Security Risk Index, MOSES - The IEA Model of Shortterm Energy Security and AESPI - Aggregated Energy Security Performance Indicator.

Shannon-Wiener Index. This index which is entirely supply-oriented, assesses participation of certain energy source in energy mix and the market share of certain supplier. The principle aim of this index is to define level of dependency of certain country upon certain supplier (Cherp, 2012).

Energy Security Index. Like the previous one, this index takes into account the prices and physical availability of certain energy sources, and this is measured by means of defining the political risk existing in the supplying country (International Energy Agency, 2007).

Supply/Demand Index for long-term security of supply ( $S / D$ Index). As a composite indicator which includes 30 individual indicators, it considers the characteristics of demand, supply and transport (Scheepers et al, 2007). 
Bjegović M., et al: National and Energy Security in Terms of Human Development

Oil Vulnerability Index. To a certain extent more comprehensive composite index which takes into consideration certain economic indicators as well, import dependency and political stability (Gupta, 2008).

Vulnerability index. "This composite index considers five different indicators: energy intensity of gross domestic product, energy import dependency, ratio of energy-related carbon emissions to TPES, electricity supply vulnerability and non-diversity in transport fuels" (Von Hippel et al, 2011). This index, unlike the previous ones, considers carbon emission as an environmental indicator.

Risky External Energy Supply. This index is entirely supply-oriented because it exclusively considers level of diversification, along with special emphasis on estimation of security of the energy transport (Blyth and Lefewre, 2004).

Socio-Economic Energy Risk. Composite index which considers the following indicators: energy sources diversification, energy resources availability and feasibility, energy intensity, energy transport, energy dependence, political stability, market liquidity and GDP (Risk of Energy Availability Common Corridors for Europe Supply Security, 2011).

The US Energy Security Risk index. Complex composite index obtained on the basis of 83 individual indicators which estimate geo-political indicators, economic development, environmental concerns and reliability (Index of US Energy Security Risk, 2011).

International Index of Energy Security Risk. This index has been defined on the basis of the previous one; it is focused on the characteristics of the world energy market and deals with: global fuel resources, fuel import, energy expenditure, energy prices and market volatility, energy intensity, energy transport and environmental concerns (International Index of Energy Security Risk, 2012).

The IEA Model of Short-term Energy Security (MOSES). The methodology is based on the application of 35 different indicators which are supply-oriented, and it considers robustness (adequacy and reliability of energy resources and infrastructure), sovereignty (sensitivity to threats from foreign actors) and resilience (capability to handle and respond to various disturbances) in the short term (Jewell, 2011).

Aggregated Energy Security Performance Indicator. This indicator considers 25 basic indicators of the effectiveness of energy policy implementation (Martchamadol and Kumar, 2013).

One of the latest measurements for quantifying energy policy effectiveness, suggested as decision-making tool, is Energy Trilemma Index, developed by the World Economic Forum (World Economic Forum, 2015). Energy Trilemma 
Index consists of three main variables (Energy Trilemma Index - monitoring the sustainability of national energy systems, 2017):

a) Energy security: Effective management of primary energy supply from domestic and external sources, reliability of energy infrastructure, and ability of energy providers to meet current and future demand.

b) Energy equity: Accessibility and affordability of energy supply across the population.

c) Environmental sustainability: Encompasses achievement of supply and demand-side energy efficiency and development of energy supply from renewable and other low-carbon sources.

Connection between energy, human development and security is complex, multi-dimensional and its characteristics have been changing in the course of history. In the very beginning, the energy was used for satisfying the basic needs of the inhabitants and it was renewable. Oil and gas became one of the principle actuators of sudden industrialization $\left(19^{\text {th }}\right.$ and beginning of $20^{\text {th }}$ century), and the energy sources became especially important during the Second World War when the energy sources proved their importance for achieving the military goals (Warr and Ayres, 2010).

After that the energy became inseparable from the concept of economic development and security. Modern concept of development of all the national economies is based on creation of such a context through which certain country can achieve the desired economic growth, preserve its sovereignty and security, along with providing of the appropriate quality of its citizens' lives. The modern man, as well as all the economic activities and functions of a society, almost always rely on energy, and shortage of the energy sources almost immediately influences upon interruption of the activities and that is why it is economic, social and security threat. Energy has become a power negotiation means on the international political scene and it is expected that such a state will remain and even intensify, because the power which other natural resources have and get is growing in the same time. (Butts, 2015).

An increasing geo-political importance of the energy sources has partially put in the background the primary goal and purpose of the energy use - creating of goods and services the ultimate goal, which is development of the mankind and welfare of the citizens. There is no human development without energy. The approach to the energy and its availability has been lately emphasized as one of the basic assumption for even development and poverty reduction (Martinez and Ebenhack, 2008). Significant efforts are being made in order to provide access to energy for all the citizens. Hundreds of millions of people have gained access to modern energy over the last two decades, especially in China and India. Rapid economic development in several developing countries, increasing urbanization and ongoing energy access programs have been important factors in this achievement (Mazur, 2012). 
Efforts to promote electricity access are having a positive impact in all regions, and the pace of progress has accelerated. The number of people without access to electricity fell to below 1.1 billion people for the first time in 2016 , with nearly 1.2 billion people having gained access since 2000, 500 million of which were in India. Most progress has been made in developing Asia, where 870 million have gained access since 2000, of which India accounts for 500 million gaining access - one of the largest electrification success stories in history (Bambawale and Savacool, 2012). For the first time there is also a positive trend in sub-Saharan Africa, where electrification efforts have been outpacing population growth since 2014. However, progress is uneven, and there are still more people without electricity today than there were in 2000 (Energy Access Outlook, 2017).

Yet, it is important to underline that the above data are related only to electricity access. Availability and affordability of fossil fuels (oil, natural gas and coal) were and remain one of the most important development and security issues for the present and the future to come.

Level of success of the sustainable development implementation which will successfully put together its various indicators and which ultimately shows the benefits each person has, can be measured in numerous ways suggested by various institutions and individuals. However, the opinion dominating in majority of the international scientific communities is the one saying that Human Development Index is probably one of the best, most reliable and most precise indicators which can be used for this purpose. "The Human Development Index (HDI) is a summary measure of average achievement in key dimensions of human development: a long and healthy life, being knowledgeable and having a decent standard of living. The HDI is the geometric mean of normalized indices for each of the three dimensions.

The health dimension is assessed by life expectancy at birth; the education dimension is measured by means of years of schooling for adults aged 25 years and more and expected years of schooling for children of school entering age. The standard of living dimension is measured by gross national income per capita. The HDI uses the logarithm of income to reflect the diminishing importance of income with increasing GNI. The scores for the three HDI dimension indices are then aggregated into a composite index using geometric mean. Refer to Technical notes for more details" (Human Development Index Report, 2017).

Human Development Index suggested by the United Nations Development Programme in 1990 as an expression of the strivings to begin to consider wellbeing of an individual as a real measure of the development success; which since then, but nowadays as well, has been measured mostly through the traditional economic indicators (Lior, Radovanović and Filipović, 2018) and represents one of the first indicators based on the multidimensional 
principle of qualification. It is important to emphasize that the "objective of the $\mathrm{HDI}$ is not to build an unassailable indicator of wellbeing, but rather to redirect attention towards people-centred development and to promote debate over how we advance the progress of societies. The HDI has achieved significant success in this field" (Stanton, 2007).

An original, and perhaps the most enduring contribution of the HDI to conceptualizing development lies in showing that levels and trends in human development can and do differ significantly from levels of income and trends in GDP growth. For example, one of the most surprising results of human development research in recent years is the lack of a significant correlation between economic growth and improvements in health and education, at least in the medium-term (Lozano and Gutierrez, 2008).

\section{Methodology of the research}

The main goal of the paper is the analysis of reliability and correlations that exist between four variables that describe energy and national security, environmental sustainability and the quality of people's life. Analysis of the Energy Trilemma Index and Human Development Index was done before and after data processing.

\subsection{Overall analysis of Energy Trilemma Index}

By inspecting the reports published by the World Energy Council, and after creating the Energy Trilemma Index (in this case, the Reports for 2011, 2014 and 2017), the following general metrological observations can be made:

a) Reports until 2015 show that the Energy Trilemma Index is essentially a composite index, which consists of three indicators: energy security, energy equity and environmental sustainability;

b) In the 2017 report, the country context is introduced as the fourth indicator;

c) The reports do not provide insight into the methodology used to conceive each of the four listed indicators;

d) Only a descriptive explanation is provided, without a clear insight into the indicator number, type and unit of measurement used to obtain each of these four indicators;

e) If it is assumed that the aggregation method has been used in the design of the indicator, there is no information which specific aggregation method has been applied;

f) There is no information as to how the four indicators are enclosed in the final Index. By inspecting the Report, it is evident that each 
indicator is assigned a value of 0 to 2 , and accordingly, the maximum value is 8 , but there is no insight into what is quantified and in what way;

g) The fact that energy security and environmental sustainability are very often contradicted is not recognized by this Index at all. Namely, it is based on the fact that the values are simply summed up, although the provision of sufficient energy (increasing the value of Energy Security) always results in environmental damage (a decrease in Environmental Sustainability). In the case of Index, values are summed up, because it is assumed that the connection between the four indicators is always only positive, which is absolutely not the case;

h) The introduction of the fourth context (Country context) triggers a whole series of controversy. Certainly, in order to ensure safe and quality human development, the situation in a particular country is certainly important, and that indicator is useful, but again there is no indication of the way this indicator is conceptualized.

Overall conclusion of this part of the research is that, even though Energy Trilemma Index (its concept itself) is developed in order to serve as decisionmaking support tool and to promote sustainable energy future, there are methodological obstacles in its full implementation, mainly because of very composition.

\subsection{Statistical analysis of Energy Trilemma Index concept}

The Spearman's rank-order correlation is the nonparametric version of the Pearson product-moment correlation. The Spearman correlation coefficient is based on the ranked values for each variable rather than the raw data, and therefore, more appropriate for this research than Pearson, or Kendal's Tau. Spearman correlation coefficients can range in value from -1 to +1 . The formula for the Spearman rank correlation coefficient when there are no tied ranks (Hauke and Kossowski, 2011):

$$
\rho=1-\frac{6 \sum d_{i}^{2}}{n\left(n^{2}-1\right)}
$$

Where $d^{2}$ is the squared difference in ranks for each observation and $n$ is the sample size.

Research variables include four variables, three of which are constituents of Energy Trilemma Index; and Human Development Index, as fourth independent (control) variable.

Research sample includes 33 countries divided in three groups: 
- 13 most developed countries in the world (Denmark, Switzerland, Sweden, Netherlands, United Kingdom, Germany, France, Norway, Finland, New Zealand, Austria, USA, Canada and Japan);

- 7 countries with largest energy sources (Brazil, China, India, South Africa, Russian Federation and Saudi Arabia) and

- 13 countries of SE Europe - at lower level of development (Albania, Greece, Macedonia, Montenegro, Serbia, Croatia, Slovenia, Bulgaria, Romania, Hungary, Moldova, Ukraine and Turkey).

Data processing was done for 2011, 2014 and 2017.

Data are obtained from the following documents: Energy Trilemma Reports for 2011, 2014 and 2016 - with projections for 2017 (World Energy Council) and Human Development Index Reports for 2011, 2014 and 2017 (United Nations Development Program).

\section{Results and discussion}

Research results and discussion are given by application of three statistical methods, described below.

a) Spearman's rank-order correlation (correlation between years)

In the first phase of data processing, the degree of correlation between the obtained values of each individual index in the three observed years with the highest degree of statistical significance $(p<0.01)$ was assessed. The aim of this analysis is to show if the ranks of individual countries change in the same or different direction.

Spearman's correlation coefficient has been chosen because of its suitability for analyses of this kind. First, that is a statistical measure of the strength of a monotonic relationship between paired data (which is the case in this research). A monotonic relationship is not strictly an assumption of Spearman's correlation. Spearman's correlation can be used on a nonmonotonic relationship to determine if there is a monotonic component to the association. However, in choice of data processing, it is appropriate to pick a measure of association, such as Spearman's correlation, that fits the pattern of the observed data. That is, if a scatterplot shows that the relationship between two variables looks monotonic it is acceptable to use Spearman's correlation because this will then measure the strength and direction of this monotonic relationship.

The results of this data processing phase are shown in Table 1. 
Bjegović M., et al: National and Energy Security in Terms of Human Development

Table 1. Changes of energy security, energy equity, environmental sustainability and HDI ranking in 2011, 2014 and 2017

\begin{tabular}{|c|c|c|c|c|c|}
\hline & & & 2011 & 2014 & 2017 \\
\hline \multirow{6}{*}{$\begin{array}{l}\text { Energy Security } \\
\text { Spearman's rho }\end{array}$} & \multirow{2}{*}{2011} & Correlation Coefficient & 1.000 & .925 & .631 \\
\hline & & Sig. (2-tailed) & & .000 & .000 \\
\hline & \multirow{2}{*}{2014} & Correlation Coefficient & .925 & 1.000 & $.663^{m}$ \\
\hline & & Sig. (2-tailed) & .000 & & .000 \\
\hline & \multirow{2}{*}{2017} & Correlation Coefficient & $.631^{\prime \prime}$ & 663 & 1.000 \\
\hline & & Sig. (2-tailed) & .000 & .000 & \\
\hline \multirow{7}{*}{$\begin{array}{l}\text { Energy equity } \\
\text { Spearman's rho }\end{array}$} & \multirow{2}{*}{2011} & Correlation Coefficient & 1.000 & .928 & .826 \\
\hline & & Sig. (2-tailed) & & .000 & .000 \\
\hline & \multirow{2}{*}{2014} & Correlation Coefficient & .928 & 1.000 & .834 \\
\hline & & Sig. (2-tailed) & .000 & & .000 \\
\hline & \multirow{3}{*}{2017} & Correlation Coefficient & .826 & .834 & 1.000 \\
\hline & & Sig. (2-tailed) & .000 & .000 & \\
\hline & & Sig. (2-tailed) & .000 & .000 & \\
\hline \multirow{4}{*}{$\begin{array}{l}\text { Environmental } \\
\text { sustainability }\end{array}$} & \multirow{2}{*}{2017} & Correlation Coefficient & 1.000 & $.837^{\circ 1}$ & .810 \\
\hline & & Sig. (2-tailed) & & .000 & .000 \\
\hline & \multirow{2}{*}{2014} & Correlation Coefficient & .837 & 1.000 & $.988^{\prime \prime}$ \\
\hline & & Sig. (2-tailed) & .000 & & .000 \\
\hline \multirow{2}{*}{$\begin{array}{l}\text { Spearman's } \\
\text { rho }\end{array}$} & \multirow{2}{*}{2011} & Correlation Coefficient & .810 & $.988^{\circ}$ & 1.000 \\
\hline & & Sig. (2-tailed) & .000 & .000 & \\
\hline \multirow{5}{*}{$\begin{array}{l}\text { HDI } \\
\text { Spearman's rho }\end{array}$} & \multirow[b]{2}{*}{2011} & Correlation Coefficient & 1.000 & $.968^{*}$ & $.959^{\prime \prime}$ \\
\hline & & Sig. (2-tailed) & & .000 & .000 \\
\hline & \multirow[b]{2}{*}{2014} & Correlation Coefficient & .968 & 1.000 & $.983^{\prime \prime}$ \\
\hline & & Sig. (2-tailed) & .000 & & .000 \\
\hline & 2017 & Correlation Coefficient & $.959^{\circ}$ & $.983^{\circ}$ & 1.000 \\
\hline
\end{tabular}

General observation is that during the observed years, there are no negative values, e.g. ranks of the given countries move in the same direction. It is important to note that the results are obtained at a higher degree of statistical significance $(p<0.01)$, which means that the said correlation can be considered acceptable for other countries (not included in the analysis). The highest overall level of correlation between ranks is noted in case of HDI.

b) Spearman's rank-order correlation (correlation between variables)

The second part of statistical data processing involves determining the degree of correlation between the four observed variables in the three years for which the data were used. The results of this part of the research are shown in Table 2. 
Bjegović M., et al: National and Energy Security in Terms of Human Development

Table 2. Correlation between energy security, energy equity, environmental sustainability and HDI ranking in 2011, 2014 and 2017

\begin{tabular}{|c|c|c|c|c|c|c|}
\hline \multicolumn{3}{|c|}{2011} & $\begin{array}{l}\text { Energy } \\
\text { Security }\end{array}$ & $\begin{array}{l}\text { Energy } \\
\text { Equity }\end{array}$ & $\begin{array}{l}\text { Environ. } \\
\text { Sustain. }\end{array}$ & $\mathrm{HDI}$ \\
\hline \multirow{8}{*}{$\begin{array}{l}\text { Spearman's } \\
\text { rho }\end{array}$} & \multirow{2}{*}{$\begin{array}{l}\text { Energy } \\
\text { security }\end{array}$} & $\begin{array}{l}\text { Correlation } \\
\text { Coefficient }\end{array}$ & 1.000 & $.413^{*}$ & .219 & $.450^{* *}$ \\
\hline & & Sig. (2-tailed) & & .017 & .222 & .009 \\
\hline & \multirow{2}{*}{$\begin{array}{l}\text { Energy } \\
\text { equity }\end{array}$} & $\begin{array}{l}\text { Correlation } \\
\text { Coefficient }\end{array}$ & $.413^{*}$ & 1.000 & $.490^{* *}$ & $.840^{* *}$ \\
\hline & & Sig. (2-tailed) & .017 & & .004 & .000 \\
\hline & \multirow{2}{*}{$\begin{array}{l}\text { Environment. } \\
\text { Sustainability }\end{array}$} & $\begin{array}{l}\text { Correlation } \\
\text { Coefficient }\end{array}$ & .219 & $.490^{* *}$ & 1.000 & $.613^{* *}$ \\
\hline & & Sig. (2-tailed) & .222 & .004 & & .000 \\
\hline & \multirow[t]{2}{*}{$\mathrm{HDI}$} & $\begin{array}{l}\text { Correlation } \\
\text { Coefficient }\end{array}$ & $.450^{* *}$ & $.840^{* *}$ & $.613^{* *}$ & 1.000 \\
\hline & & Sig. (2-tailed) & $\begin{array}{r}.009 \\
\end{array}$ & .000 & .000 & \\
\hline \multicolumn{3}{|c|}{2014} & $\begin{array}{l}\text { Energy } \\
\text { Security }\end{array}$ & $\begin{array}{l}\text { Energy } \\
\text { Equity }\end{array}$ & $\begin{array}{l}\text { Environ. } \\
\text { Sustain. }\end{array}$ & $\mathrm{HDI}$ \\
\hline \multirow{8}{*}{$\begin{array}{l}\text { Spearman's } \\
\text { rho }\end{array}$} & \multirow{2}{*}{$\begin{array}{l}\text { Energy } \\
\text { security }\end{array}$} & $\begin{array}{l}\text { Correlation } \\
\text { Coefficient }\end{array}$ & 1.000 & .329 & .213 & $.445^{* *}$ \\
\hline & & Sig. (2-tailed) & & .062 & .234 & .010 \\
\hline & $\begin{array}{l}\text { Energy } \\
\text { equity }\end{array}$ & $\begin{array}{l}\text { Correlation } \\
\text { Coefficient }\end{array}$ & .329 & 1.000 & $.450^{* *}$ & $.840^{* *}$ \\
\hline & & Sig. (2-tailed) & .062 & & .009 & .000 \\
\hline & \multirow{2}{*}{$\begin{array}{l}\text { Environment. } \\
\text { Sustainability }\end{array}$} & $\begin{array}{l}\text { Correlation } \\
\text { Coefficient } \\
\end{array}$ & .213 & $.450^{* *}$ & 1.000 & $.619^{* *}$ \\
\hline & & Sig. (2-tailed) & .234 & .009 & & .000 \\
\hline & \multirow[t]{2}{*}{ HDI } & $\begin{array}{l}\text { Correlation } \\
\text { Coefficient }\end{array}$ & $.445^{* *}$ & $.840^{* *}$ & $.619^{* *}$ & 1.000 \\
\hline & & Sig. (2-tailed) & .010 & .000 & .000 & \\
\hline \multicolumn{3}{|c|}{2017} & $\begin{array}{l}\text { Energy } \\
\text { Security }\end{array}$ & $\begin{array}{l}\text { Energy } \\
\text { Equity }\end{array}$ & $\begin{array}{l}\text { Environ. } \\
\text { Sustain. }\end{array}$ & $\mathrm{HDI}$ \\
\hline \multirow{8}{*}{$\begin{array}{l}\text { Spearman's } \\
\text { rho }\end{array}$} & \multirow{2}{*}{$\begin{array}{l}\text { Energy } \\
\text { security }\end{array}$} & $\begin{array}{l}\text { Correlation } \\
\text { Coefficient }\end{array}$ & 1.000 & $.565^{* *}$ & .213 & $.633^{* *}$ \\
\hline & & Sig. (2-tailed) & & .001 & .235 & .000 \\
\hline & \multirow{2}{*}{$\begin{array}{l}\text { Energy } \\
\text { equity }\end{array}$} & $\begin{array}{l}\text { Correlation } \\
\text { Coefficient }\end{array}$ & $.565^{*}$ & 1.000 & $.433^{*}$ & $.897^{* *}$ \\
\hline & & Sig. (2-tailed) & .001 & . & .012 & .000 \\
\hline & \multirow{2}{*}{$\begin{array}{l}\text { Environment. } \\
\text { Sustainability }\end{array}$} & $\begin{array}{l}\text { Correlation } \\
\text { Coefficient }\end{array}$ & .213 & $.433^{*}$ & 1.000 & $.519^{* *}$ \\
\hline & & Sig. (2-tailed) & .235 & .012 & & .002 \\
\hline & \multirow[t]{2}{*}{ HDI } & $\begin{array}{l}\text { Correlation } \\
\text { Coefficient }\end{array}$ & $.633^{* *}$ & $.897^{* *}$ & $.519^{* *}$ & 1.000 \\
\hline & & Sig. (2-tailed) & .000 & .000 & .002 & \\
\hline
\end{tabular}

Results show that the highest correlation and Sig. (2-tailed) exists between all three components of Energy Trilemma Index and HDI. Correlation between all variables is smallest in 2011, but it is becoming more significant in 2017. The highest positive correlation in the whole analysis is recorded in case of 
Bjegović M., et al: National and Energy Security in Terms of Human Development

correlation between ranks of energy equity and HDI in 2017 (0.887), while the smallest is between energy security and energy sustainability (0.213) in 2014 .

Considering changes in three observed years, it can be noted, first, that, during years, correlation between energy security and energy equity is almost identical $(0.490,0.450,0.433)$. The same values, without significant changes, can be found in case of correlation between energy equity and environmental sustainability. Significant changes can be found only in case of correlation between $\mathrm{HDI}$ and other three variables. All these remarks are leading to the conclusion that HDI is best defined indicator in Energy Trilemma Index. Other three indicators must be subject of reconsideration.

\section{c) Descriptive statistics}

In order to get deeper insight into quality (reliability, relevance and usability) of each indicator used, basic descriptive statistics is done.

Table 3. Mean and median values of energy security, energy equity, environmental sustainability and HDI ranking in 2011, 2014 and 2017

\begin{tabular}{|c|c|c|c|c|}
\hline \multicolumn{2}{|r|}{ Energy Security } & 2011 & 2014 & 2017 \\
\hline \multirow{2}{*}{$\mathrm{N}$} & Valid & 33 & 33 & 33 \\
\hline & Missing & 0 & 0 & 0 \\
\hline \multicolumn{2}{|c|}{ Mean } & 45.91 & 45.97 & 33.61 \\
\hline \multicolumn{2}{|c|}{ Median } & 40.00 & 43.00 & 25.00 \\
\hline \multicolumn{2}{|c|}{ Energy Equity } & 2011 & 2014 & 2017 \\
\hline \multirow{2}{*}{$\mathrm{N}$} & Valid & 33 & 33 & 33 \\
\hline & Missing & 0 & 0 & 0 \\
\hline \multicolumn{2}{|c|}{ Mean } & 42.30 & 46.15 & 42.52 \\
\hline \multicolumn{2}{|c|}{ Median } & 28.00 & 42.00 & 38.00 \\
\hline \multicolumn{2}{|r|}{$\begin{array}{l}\text { Environmental } \\
\text { Sustainability }\end{array}$} & 2011 & 2014 & 2017 \\
\hline \multirow{2}{*}{$\mathrm{N}$} & Valid & 33 & 33 & 33 \\
\hline & Missing & 0 & 0 & 0 \\
\hline \multicolumn{2}{|c|}{ Mean } & 60.61 & 61.12 & 52.79 \\
\hline \multicolumn{2}{|c|}{ Median } & 45.00 & 45.00 & 42.00 \\
\hline \multicolumn{2}{|r|}{ HDI } & 2011 & 2014 & 2017 \\
\hline \multirow{2}{*}{$\mathrm{N}$} & Valid & 33 & 33 & 33 \\
\hline & Missing & 0 & 0 & 0 \\
\hline \multicolumn{2}{|c|}{ Mean } & 45.73 & 45.58 & 44.12 \\
\hline \multicolumn{2}{|c|}{ Median } & 38.00 & 34.00 & 38.00 \\
\hline
\end{tabular}


Observing mean and median values of energy security ranges in the three observed years, it is seen that they are equal in 2011 and 2014 (40.00 and 43.00), but it falls in 2017 (25.00). The deviations are highest in the case of energy equity $(28.00,42.00$ and 38$)$, which clearly indicate that energy equity is a poorly conceptualized variable.

The mean degree of variation was recorded in the case of Energy security indicator, and the least variations exist in the case of environmental sustainability and $\mathrm{HDI}$. This research, like many of the previous ones, has shown that HDI is a very stable and reliable indicator.

\section{Conclusion}

Since many factors are often unpredictable, and their consequences are hardly observable and measurable, the modern world is facing a number of development challenges. Ensuring stable development (in every sense) is the priority of any national economy. In order to achieve this in reality, it is necessary to develop certain development strategies based on realistic indicators that will respect national specificities and priorities. The complex geopolitical changes that arose after 2000 brought about the abovementioned changes. In the situation where the world faces a number of security challenges and conflicts, the issue of national security comes to the forefront. Energy security is part of the national security system, and it implies the ability of a given country to provide enough energy (by type and amount) to carry out economic activities for the needs of the population, without compromising the quality of the environment and at affordable prices. Only in this case, the national economy will be able to provide a satisfactory quality of life and social welfare of its citizens.

The modern world is clearly divided into countries that are rich in energy sources and countries that are dependent on imported energy. The complex geopolitical changes and volatility of the energy market additionally complicate the already complex issue of selecting and implementing an adequate national strategy that will ensure the stability and security of citizens. When it comes to energy security, the issue of strategic planning and decision-making becomes increasingly complex. Energy management involves a whole series of complex procedures and the synchronization of a whole range of participants, as well as international cooperation - all of which implies that a number of strategically important decisions need to be made. Namely, all decisions that are made in connection with energy policy have their short and long-term consequences for the national stability, security and welfare of the citizens, as well as for the position of the country on the international geopolitical scene. With the aim of making the highest quality decisions, a number of tools and techniques for decision-making support have 
Bjegović M., et al: National and Energy Security in Terms of Human Development

been developed, although there is still no consensus on their acceptability. One of the ways to support decision-making is to use and process specific data, that is quantifications, which is a precondition for more precise planning and analysis of scenarios. The Energy Trilemma Index is an indicator that is the subject of the analysis in this paper.

Main objective of this paper is to assess reliability of Energy Trilemma Index for energy management, by assessment of ranking of its main components (energy security, energy equity and environmental sustainability) among themselves and with Human Development Index - as main objectives for more sustainable energy future. Main findings are: a) there is strong positive correlation between ranking per years in case of all chosen variables; b) HDI records highest correlation, which means that this indicator is theoretically adequately conceived; c) energy security and environmental sustainability can be viewed as quality indicators, and d) energy equity varies significantly, which raises the question of whether it is adequately conceptualized.

Main policy recommendation rises from methodological finding of this research: cautious use of Energy Trilemma Index as decision-making tool, because this research proves shortcomings of energy equity component (related to its very essence and not adequate methodological / theoretical base). In addition, policy makers must have in mind that energy security and environmental sustainability are often opposed so further policy actions should be based on priorities. Adjustments of measurement (according to specificities of countries - level of economic, energy import) are highly recommended. On the other hand, Human Development Index showed its reliability and stability from methodological point of view.

\section{References}

Al-mulali, U., \& Che, S.C.N.B. (2018). The impact of coal consumption and CO 2 emission on economic growth. Energy Sources, Part B: Economics, Planning, and Policy, 13(4), 218-223. doi:10.1080/15567249.2012.661027

Badeeb, R.A., Lean, H.H., \& Clark, J. (2017). The evolution of the natural resource curse thesis: A critical literature survey. Resources Policy, 51, 123-134. doi:10.1016/j.resourpol.2016.10.015

Bambawale, M.J., \& Sovacool, B.K. (2012). Energy Security: Insights from a Ten Country Comparison. Energy \& Environment, 23(4), 559-586. doi:10.1260/0958305x.23.4.559

Bilgen, S., \& Sarıkaya, İ. (2018). Energy conservation policy and environment for a clean and sustainable energy future. Energy Sources, Part B: Economics, Planning, and Policy, 13(3), 183-189. doi:10.1080/15567249.2017.1423412

Bildirici, M.E., \& Bakirtas, T. (2014). The relationship among oil, natural gas and coal consumption and economic growth in BRICTS (Brazil, Russian, India, China, 
Bjegović M., et al: National and Energy Security in Terms of Human Development

Turkey and South Africa) countries. Energy, 65, 134-144. doi:10.1016/j.energy.2013.12.006

Blyth, W., \& Lefevre, N. (2004). Energy Security and Climate Change. Paris: International Energy Agency.

Browne, J. (2018). The Regulatory Gift: Politics, regulation and governance. Regulation \& Governance, doi:10.1111/rego.12194

Butts, K.H. (2015). Geopolitics of Resource Scarcity. The Penn State Journal of Law \& International Affairs, 13-27; 3.

Cătălin, V. (2016). Changes of EU industrial policy and its effects on Romania's industrial paradigm. Industrija, 44(4), 197-210. doi:10.5937/industrija44-12011

Cherp, A., Adenikinju, A., Goldthau, A., Hernandez, F., Hughes, L., Jansen, J., . . . Fisk, D.J. (2009). Energy and Security. In T.B. Johansson, N. Nakicenovic, A. Patwardhan, L. Gomez-Echeverri, T.B. Johansson, N. Nakicenovic, . . . L. Gomez-Echeverri (Eds.), Global Energy Assessment (GEA). (pp. 325-384). Cambridge: Cambridge University Press (CUP). doi:10.1017/cbo9780511793677.011

Energy Access Outlook. (2017). Paris: International Energy Agency.

-International Energy Agency. (2007). Energy Security and Climate Policy. Paris.

-World Energy Council. (2015). Energy Trilemma Index: Benchmarking the sustainability of national energy systems. London.

-World Energy Council. (2017). Energy Trilemma Index: Monitoring the sustainability of national energy systems. London.

Gent, D., \& Tomei, J. (2017). Electricity in Central America: Paradigms, reforms and the energy trilemma. Progress in Development Studies, 17(2), 116-130. doi: $10.1177 / 1464993416688826$

Gupta, E. (2008). Oil vulnerability index of oil-importing countries. Energy Policy, 36(3), 1195-1211. doi:10.1016/j.enpol.2007.11.011

Hauke, J., \& Kossowski, T. (2011). Comparison of Values of Pearson's and Spearman's Correlation Coefficients on the Same Sets of Data. Quaestiones Geographicae, 30(2), 87-93. doi:10.2478/v10117-011-0021-1

-United Nations Development Programme. (2017). Human Development Index Report.

-US Chamber of commerce. (2011). Index of US Energy Security Risk. Washington DC. Ed..

-US Chamber of commerce. (2012). International Index of Energy Security Risk. Washington DC: US Chamber of commerce. Ed.

Jarvis, D.S.L. (2010). Institutional processes and regulatory risk: A case study of the Thai energy sector. Regulation \& Governance, 4(2), 175-202. doi:10.1111/j.1748-5991.2010.01077.x

Jewell, J. (2011). The IEA Model of Short-term Energy Security (MOSES) Primary Energy Sources and Secondary Fuels. Paris: International Energy Agency.

Jiang, N. (2018). Strategic trends for future energy policy: Evidence from China. Energy Sources, Part B: Economics, Planning, and Policy, 13(3), 165168. doi:10.1080/15567249.2017.1416703

Lederer, M. (2012). Market making via regulation: The role of the state in carbon markets. Regulation \& Governance, 6(4), 524-544. doi:10.1111/j.17485991.2012.01145.x

Lior, N., Radovanović, M., \& Filipović, S. (2018). Comparing sustainable development measurement based on different priorities: sustainable development goals, 
Bjegović M., et al: National and Energy Security in Terms of Human Development

economics, and human well-being-Southeast Europe case. Sustainability Science, 13(4), 973-1000. doi:10.1007/s11625-018-0557-2

Lozano, S., \& Gutierrez, E. (2008). Data envelopment analysis of the human development index. International Journal of Society Systems Science, 1(2), doi:10.1504/ijsss.2008.021916

Martchamadol, J., \& Kumar, S. (2013). An aggregated energy security performance indicator. Applied Energy, 103, 653-670. doi:10.1016/j.apenergy.2012.10.027

Martínez, D.M., \& Ebenhack, B.W. (2008). Understanding the role of energy consumption in human development through the use of saturation phenomena. Energy Policy, 36(4), 1430-1435. doi:10.1016/j.enpol.2007.12.016

Mazur, A. (2011). Does increasing energy or electricity consumption improve quality of life in industrial nations. Energy Policy, 39(5), 2568-2572. doi:10.1016/j.enpol.2011.02.024

Muñoz-Delgado, B. (2011). Energy security indices in Europe. In Economic Challenges for Energy - Workshoop, Economic challenges for energy workshop, February 7-8th, Madrid, Spain.

Radovanović, M., Filipović, S., \& Golušin, V. (2018). Geo-economic approach to energy security measurement - principal component analysis. Renewable and Sustainable Energy Reviews, 82, 1691-1700. doi:10.1016/j.rser.2017.06.072

Rakic, B., Stanojevic, J., \& Radjenovic, T. (2015). Political cycles' influence on inflation and unemployment. Industrija, 43(2), 89-104. doi:10.5937/industrija43-7922

Ristić, V., Mirković-Isaeva, O., \& Vasić, B. (2018). Upravljanje prirodnim bogatstvom prokletstvo prirodnih resursa i socio-ekonomski razvoj. Industrija, 46(2), 131150. doi:10.5937/industrija46-17194

Risk of Energy Availability Common Corridors for Europe Supply Security, Summary Report. (2011). Poject funded by EC FP7 under the theme "Energy Security of Supply", Summary Report, Final Workshop, Brussels May 13th.

Scheepers, M., Seebregts, A., de Jang, J., \& Maters, H. (2007). EU Standards for Energy Security of Supply, ECN/Clingendael International Energy Program. Petten, The Netherlands: European Commission, Directorate-General for Energy and Transport.

Stanton, E.A. (2007). The Human Development Index: A History. In Global Development and Environment Institute, Tufts University, USA, working paper No. 127.

von Hippel, D., Suzuki, T., Williams, J.H., Savage, T., \& Hayes, P. (2011). Energy security and sustainability in Northeast Asia. Energy Policy, 39(11), 6719-6730. doi:10.1016/j.enpol.2009.07.001

Warr, B.S., \& Ayres, R.U. (2010). Evidence of causality between the quantity and quality of energy consumption and economic growth. Energy, 35(4), 1688-1693. doi:10.1016/j.energy.2009.12.017

Xue, B., \& Sun, Z. (2018). Economics of hydropower energy: A critical assessment. Energy Sources, Part B: Economics, Planning, and Policy, 13(1), 33-36. doi:10.1080/15567249.2017.1402102

Zong, H., Cao, Y., \& Liu, Z. (2018). Energy security in Group of Seven (G7): a quantitative approach for renewable energy policy. Energy Sources, Part B:

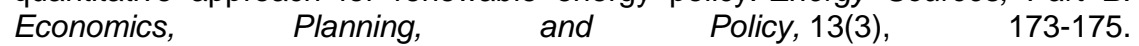
doi:10.1080/15567249.2017.1422053 